F Castro-Giner, F Kauffmann, R de Cid, M Kogevinas

Occup Environ Med 2006;63:776-786. doi: 10.1136/oem.2004.019216

A sthma is a complex disease with a diverse genetic and environmental component. ${ }^{1}$ Asthma shows a high level of phenotypic heterogeneity characterised by obstruction of the airways of the lung and is related with atopy, bronchial hyperresponsiveness (BHR), and increased IgE levels. Over the last decades asthma has become a major cause of morbidity in children from developed countries with an estimated prevalence of $5-10 \% .{ }^{2-5}$ It has been estimated that about 300 million persons worldwide have asthma (http://www.ginasthma.com/).

Studies in twins and family studies indicate that the genetic component of asthma is likely to be high, ${ }^{6-9}$ although the individual genes identified have only modest effects and an unknown pattern of inheritance. The most common chromosomal linkage regions observed in genome-wide linkage studies are 2q14-q32, 5q31-q33, 6p21.3, 7q31, 11q13, 12q14.3-q24.31, 13q14, 14q11.2q13, 16p21, 17q11.2, and 20p13. ${ }^{4}$ Several asthma and atopy genes have been identified by positional cloning including the genes ADAM33, PHF11, GPRA, DPPIO, and SPINK5, ${ }^{10}$ and numerous other genes have been investigated as candidate genes based on their function.

Many environmental factors have been associated with incidence or prevalence of asthma although there is still limited knowledge of major causes of asthma in the general population. Air pollutants (particles, diesel exhaust, PAHs) are inducers of oxidative stress that could play a role in allergic inflammation and in inducing acute asthma exacerbations. ${ }^{11}{ }^{12}$ Several studies have associated asthma with different indoor air pollutants: dampness, newly painted dwelling, indoor higher levels of $\mathrm{CO}_{2}$, exposure to $\mathrm{NO}_{2}$ (gas cookers), formaldehyde, and total concentration of VOCs and higher levels of terpenes..$^{12}$ Passive smoking/environmental tobacco smoke (ETS) is a well studied exposure, that has been associated with respiratory symptoms, lower lung function, BHR, severity of asthma, and increasing levels of total IgE. ${ }^{14}$ Occupational exposures cause around $15 \%$ of adult asthma. ${ }^{15}$ Around 250 specific occupational exposures have been associated with asthma; occupations at high risk include farmers, painters, plastics workers, and cleaners. ${ }^{16}$

Timing of exposure seems to be important. This is exemplified by the low asthma and atopy risk in children growing up in farms that are more exposed to infections and allergens. ${ }^{17}{ }^{18}$ This low risk has been attributed to what has been described as the "hygiene hypothesis", postulating that lack of contact with infectious agents in early age could prevent the evolution of the Th2 immune profile of the newborn (pro-allergic) towards a Thl profile (anti-infectious). ${ }^{19}$

An individual's predisposition to disease may affect the response to environmental or occupational exposures. Increasing evidences in the last decade suggest that gene-environment interactions play a critical role in pathogenesis of complex diseases like asthma, with multiple genes (each one with modest effects) operating in conjunction with multiple environmental or occupational exposures. Studies of interactions of genes and the environment may help elucidate the mechanisms of disease, identifying specific genes, or exposures involved in the same pathway. This information could also help design strategies of intervention and preventive advice, and of therapeutic intervention on the population at risk. ${ }^{20}$

The meaning of "interaction" remains controversial in biomedical research. A more biological oriented definition refers to interaction as the co-participation of two factors (gene and environment) in the same causal mechanism of disease. ${ }^{4}$ From a statistical point of view, geneenvironment interaction would imply a change in the effect of exposure to an environmental factor due to a genetic variant, or vice versa. ${ }^{21}{ }^{22}$ A statistical interaction does not necessarily imply a biological interaction. Furthermore, when discussing statistical interactions it is important to define the measure of risk examined and the type of model used, for example multiplicative or additive models.

Several categories of genes have been examined in studies on gene-environment interactions in asthma. Genes have been selected on the basis of previous evidence of involvement in asthma or related phenotypes, or previous evidence of interaction with the environmental cause under study irrespective of prior evidence of asthma. Examples of different categories of genes include: (i) genes that could be involved in the metabolism of substances producing asthma (e.g. N-acetyl transferases and isocyanates); (ii) genes induced in response to oxidative stress (e.g. GSTs, NQO1) which are related to exposures that induce asthma by production of reactive oxygen 
species (ROS) responsible for inflammatory changes in airways; (iii) genes involved in immune pathways (HLAII group, TLR, CD14, TNF $\alpha$ ) related to exposures that unleash immunological responses, for example endotoxins; and (iv) genes that control bronchodilator response and airway tone (ADRB2) which could modify the susceptibility and response to exposures related with asthma.

Evaluation of the literature is complicated because of the use of a great variety of phenotypes in the available studies such as asthma-like symptoms, occupational asthma, nonspecific and specific airway hyperresponsiveness, immunological sensitisation, total IgE, reduced lung function, bronchodilator responses, and the inconsistent approaches used in documenting these outcomes.

In this article we review studies that examine interactions between genes, environmental and occupational exposures, and asthma and related phenotypes. We present the most relevant results and discuss specific methodological issues regarding these studies.

SEARCH METHODOLOGY AND SELECTION CRITERIA Bibliographic searches were done online through PubMed (http://www.ncbi.nlm.nih.gov/entrez/), searches in our own archives, and backward searches of articles cited in earlier literature reviews or original papers. We did not apply any restriction of year of publication. The keywords used in the PubMed search were "asthma AND (gene OR genes OR polymorphism) AND (environment OR environmental OR occupational) AND (association OR interaction)". We repeated the same search for "atopy" and for "bronchial hyperresponsiveness". We initially identified more than 180 papers with some reference on gene-environment interactions in asthma and related phenotypes. From those 180, 43 studies were assessing gene-environment interactions. For these review we selected 30 original articles on the basis of the following criteria: (i) articles that had information on both genetic and environmental or occupational factors; (ii) studies that assess occupational exposures, indoor and outdoor air pollutants, ETS or tobacco smoking, excluding studies of aspirin exposures; ${ }^{23-25}$ and (iii) studies that included around 100 or more subjects. Most studies included less than 200 subjects $(n=23)$, with only nine studies having more than 500, and four of these, more than 1000. Two of the selected studies were experimental ${ }^{26}{ }^{27}$ while all others were observational.

\section{TYPE OF STUDIES}

The classical case-control design (or variants such as family case-control or case-case studies) has been the basic design in studies evaluating gene-environment interactions. Studies conducted in adults focusing on occupational and environment exposures were rarely cohort studies. The case-control design has several advantages when examining personal characteristics such as genetic polymorphisms that do not vary over time. These studies, on the other hand, carry also all the potential biases of case-control studies including selection bias, recall bias, and confounding. In occupational asthma studies evaluating gene-environment interaction, exposure of cases and controls relates to exposures defined by the place of work and not by subject's report and there is a low probability of differential recall bias. Non-differential misclassification (of exposures and outcomes), however, certainly occurs to a different degree. Selection bias (for example, from the inclusion of prevalent rather than incident cases) and confounding have seldom been evaluated.

A special type of confounding in genetic case-control studies is population stratification that occurs from unmeasured difference between subgroups of the study population of different genetic background. Family based case-control designs avoid this confounding, using related individuals of cases that are matched, by definition, for population structure. The genetic variants inherited by cases, are compared with the untransmitted variants, present in related controls. For example, Colilla et $a l^{28}$ used 144 families from affected individuals using a genome-wide analysis and testing for environmental tobacco smoke (ETS). This design, however, requires more genotyping (which means more expensive studies) than classical case-control studies and also is more complicated regarding the selection of subjects. ${ }^{29}$

Case-case studies are similar to case-control but they are limited to cases and compare them in relation to the presence of a genetic trait or exposure. These studies are optimal for examining interactions but cannot evaluate without further information whether a trait or exposure affects the overall occurrence of the disease since they lack controls, and are very sensitive to population stratification. ${ }^{29}$

\section{IDENTIFICATION OF GENES AND SNPs}

Different strategies have been used to assess the association of asthma and genetic variants. Most of the studies reviewed have applied a candidate-gene approach, selecting genes which had been shown in previous studies to be associated with asthma or the exposure. This approach is, at present, the most effective tool for studying complex diseases at the population level, ${ }^{30}$ because it allows testing the interaction of a relatively small number of selected genes with other genes and environmental factors. These studies are based on the prior assumption that variations in the study genes could be related to the disease. One of the limitations of this approach is that the success of the study will depend on previous knowledge and ability for selection of candidates. Genomewide association studies and linkage studies (which can be followed by positional cloning) avoid this problem including variants without a priori hypotheses. Environmental exposures have rarely been included in this type of study. Colilla et $a^{28}$ carried out a genome-wide linkage study and stratified the sample by ETS exposure. They then identified specific chromosome regions (e.g. 1p, 5q, 17p) that were associated with asthma only among exposed subjects and speculated that this was due to the function of the gene in relation to the specific exposure examined (ETS). Despite the advantage of genome-wide studies, candidate-gene approach has been considered until now as more effective to identify genes involved with low relative risk association characteristic of complex diseases like asthma. ${ }^{30} 31$

\section{GENE-ENVIRONMENT INTERACTIONS IN ASTHMA}

A summary of the interactions that have been examined is presented in table 1 . The exposures and genes most frequently examined are then discussed in more detail.

\section{OCCUPATIONAL EXPOSURES: ISOCYANATES}

Isocyanates are among the most important causes of occupational asthma, and in specific settings have been described to cause asthma symptoms in $5-15 \%$ of those exposed. ${ }^{32}{ }^{33}$ Although the pathogenic mechanism remains 
Table 1 Interactions assessed between genes and environment in asthma and related phenotypes

\begin{tabular}{|c|c|c|}
\hline Exposure & Genes & Alleles \\
\hline \multicolumn{3}{|l|}{ Environment } \\
\hline \multirow[t]{6}{*}{ Outdoor air pollution } & GSTMI, GSTPI, GSTT1 & null, lle105 \\
\hline & ADRB2 & $\operatorname{Arg} 16, \operatorname{Arg} 27$ \\
\hline & ILARA & \\
\hline & $\mathrm{CCl} 6$ & \\
\hline & TNF, LT $\alpha$ & \\
\hline & NQOI & \\
\hline \multirow[t]{4}{*}{ Indoor air pollution } & TLR4 & \\
\hline & HLAII-DRB1 & \\
\hline & CD14 & \\
\hline & 1L9 & \\
\hline ETS & GSTMI, GSTTI & \\
\hline Other & HLAII-DRB 1, HLAII-DQ & \\
\hline \multicolumn{3}{|l|}{ Occupational } \\
\hline \multirow[t]{7}{*}{ Isocyanates } & GSTP1, GSTM1, GSTM3, & \\
\hline & $\begin{array}{l}\text { GSTT1, } \\
\text { HLAll HIAI }\end{array}$ & \\
\hline & TNF & DQA1, DQB1 \\
\hline & & DRB1,2,3,4 \\
\hline & TCR V $\beta-$ & \\
\hline & & \\
\hline & NAT, NAT2 & \\
\hline \multirow[t]{6}{*}{ Aluminium production } & ADRB2 & \\
\hline & High affinity receptor & \\
\hline & of $\lg E$ & \\
\hline & $\begin{array}{l}\text { TNF } \\
\text { AAT }\end{array}$ & \\
\hline & HLA & \\
\hline & Allotypes lg & \\
\hline \multirow{2}{*}{$\begin{array}{l}\text { Acid anhydride } \\
\text { Farming }\end{array}$} & HLAll & $\mathrm{DP}, \mathrm{DQ} 5, \mathrm{DR} 1$ \\
\hline & TLR2, TLR4 & \\
\hline Wood & $\begin{array}{l}\text { AAT } \\
\text { HLAll }\end{array}$ & DRB 1, DQB1 \\
\hline Laboratory animals & HLAI & $\begin{array}{l}\text { DQB1, DRB1 } \\
\mathrm{A}, \mathrm{B}, \mathrm{C}\end{array}$ \\
\hline Platinum salt complexes & HLAll & $\begin{array}{l}\text { DRB, DPB, DQA, } \\
\text { DQB }\end{array}$ \\
\hline \multicolumn{3}{|l|}{ Lifestyles and others } \\
\hline Smoking & ADRB2, CD14 & \\
\hline \multirow[t]{2}{*}{ Drugs } & HLAll & $\mathrm{DPB} 1, \mathrm{DRB} 1$ \\
\hline & EP2 & \\
\hline
\end{tabular}

GSTM1, glutathione S-transferase, mu-1; GSTP1, glutathione Stransferase, $\mathrm{Pl}$; GSTT1, glutathione S-transferase, theta-1; ADRB2, beta2-adrenergic receptor; IL4RA, interleukin 4 receptor alpha; CC16, Claro cell secretory protein; TNF, tumour necrosis factor alpha; Lta, lymphotoxin alpha; NQO1, NAD(P)H dehydrogenase, quinone 1; TLR4, toll like receptor 4; HLAll, human leucocyte antigen class II; CDI4, monocyte differentiation antigen CD14; IL9, interleukin 9; HLAl, human leucocyte antigen class $I$; TCR $V \beta$, T-cell receptor variable $\beta$ gene segment; AAT, $\alpha-1$ antitrypsin; NAT1 or 2: N-acetyltransferase 1 or 2 TLR2, toll like receptor 2; EP2, prostaglandin $E_{2}$ receptor subtype 2 .

unclear, there is evidence of interaction between exposure to isocyanates with genetic factors. ${ }^{34}$

An immunological mechanism has been suggested to explain sensitisation to isocyanates. ${ }^{35-37}$ Isocyanate induced asthma is characterised by persistent activation of lymphocytes and chronic expression of proinflammatory cytokines, ${ }^{38}{ }^{39}$ and these compounds present morphological and functional similarities with some allergens that induce asthma.$^{40}$ HLA II interactions have been evaluated by several studies; three studies ${ }^{41-43}$ associated HLA II in isocyanate induced asthma, suggesting that the $D Q B I^{*} 0503$ allele contributes to the susceptibility to isocyanates while the $D Q B 1^{*} 0501$ allele confers resistance, furthermore suggesting a critical role of the residue 57 of DQBl gene product, ${ }^{41}$ with a sixfold increased asthma risk among homozygotes for DQB1 $\operatorname{Asp}^{57+}(\mathrm{p}=0.011)$. By contrast, the studies of Rihs et $a l^{44}$ and Bernstein $e t a l^{45}$ did not observe an interaction with HLA II. Nevertheless, unlike allergic asthma, isocyanate induced asthma is frequently produced in non-atopic and non-smokers. ${ }^{40}$ Immunological mechanisms possibly explain approximately only $20-30 \%$ of cases. ${ }^{46}$

Reactive oxygen species (ROS) derived from oxidative stress are one of the causes of persistent airway inflammation, ${ }^{47}$ characteristic of isocyanate induced asthma. ${ }^{40}{ }^{48}$ It has been suggested that genetic susceptibility to isocyanate induced asthma may be related to differences in detoxification of ROS through antioxidant metabolism. Glutathione S-transferases (GSTs) are a family of enzymes (categorised into four main classes: alpha, mu, pi, and theta) that play an important role in detoxification of a wide variety of oxidative substances and protect cells from ROS. Several association studies show the role of this family of enzymes in asthma pathogenesis. ${ }^{49-51}$ Piirila et $a l^{48}$ have evaluated different polymorphisms of GST (genes $\mathrm{Ml}, \mathrm{M} 3, \mathrm{Pl}$, and T1) in 182 workers exposed to different types of diisocyanates. Workers carrying the null allele of GSTMI had a relative risk of 1.9 (95\% CI 1.0 to 3.5) for isocyanate induced asthma. Moreover, GSTPI Val105/105Val genotype was associated with lack of diisocyanate specific IgE antibodies ( $\mathrm{OR}=5.5 ; 95 \%$ CI 1.2 to 26.0). A similar result was seen by Wikman et $a l^{52}$ that observed a joined effect of GSTMI null genotype and NATI and NAT2 alleles. Mapp et $a l^{40}$ assessed interaction of GSTPl gene with isocyanate induced asthma in 131 exposed workers and also observed a protective role of Val105/105Val genotype against asthma and bronchial hyperresponsiveness (BHR).

\section{OTHER OCCUPATIONAL EXPOSURES}

Gene-environment interactions in asthma produced by aluminium potroom emissions among aluminium smelter workers, have been evaluated in two studies. ${ }^{53}{ }^{54}$ None of these studies obtained significant results for the genes assessed (ADRB2, high affinity receptor of IgE, TNF, $\alpha-1$ antitripsine, HLA, allotypes $\mathrm{Ig})$. Young et al $l^{55}$ found that HLAII-DR 3 could be a risk factor for sensitisation among workers exposed to acid anhydrides $(\mathrm{OR}=6 ; \mathrm{p}=0.05)$, although they only studied a sample of 30 cases and 28 controls. Sensitisation to organic acid anhydrides was assessed in relation to HLAII-DQ5 and HLAII-DR1 genotypes, and HLAII-DQB1*0501 was identified conferring a risk $(\mathrm{OR}=3.0 ; 95 \%$ CI 1.2 to 7.4$))^{.56}$

Endotoxin has been evaluated both as an occupational exposure in farms in adults ${ }^{55}$ and as an environmental exposure in children..$^{57-59}$ The effect is complex and seems to depend on the level and the time-window of exposure, and to be further modulated by genetic factors, such as TLR4, TLR2, and CD14..$^{57-59}$

Among young farmers (and not rural controls), Pl rare genotypes ( SZ, SS, ZZ) of alpha-1-antitrypsin were associated with greater sensitisation towards dust mites and with bronchial hyperresponsiveness, ${ }^{60}$ showing the pleiotropic effect of farm exposures. ${ }^{18}$

One study examined exposure to red cedar (wood) and suggested a possible interaction with some HLAII-DQBI genotypes. ${ }^{61}$ An increased risk of asthma was observed for ${ }^{*} 0603(\mathrm{OR}=2.9 ; \mathrm{p}=0.05)$ and ${ }^{*} 0302(\mathrm{OR}=4.9 ; \mathrm{p}=0.02)$ genotypes, and for 0401-0302 haplotype (OR $=10.3$; $\mathrm{p}=0.01)$. A lower risk was found for the *0501 genotype $(\mathrm{OR}=0.3 ; \mathrm{p}=0.02)$ and 0101-0501 haplotype $(\mathrm{OR}=0.3$; $\mathrm{p}=0.04)$. Laboratory animal allergens interaction with HLAII class genes have been assessed in two studies. ${ }^{62}{ }^{63}$ In the study by Jeal et al, ${ }^{62}$ the HLAII-DRB107 genotype was involved in sensitisation ( $\mathrm{OR}=1.8 ; 95 \% \mathrm{CI} 1.1$ to 2.9 ) and work related chest symptoms $(\mathrm{OR}=2.9 ; 95 \% \mathrm{CI} 1.6$ to 5.4$)$, 


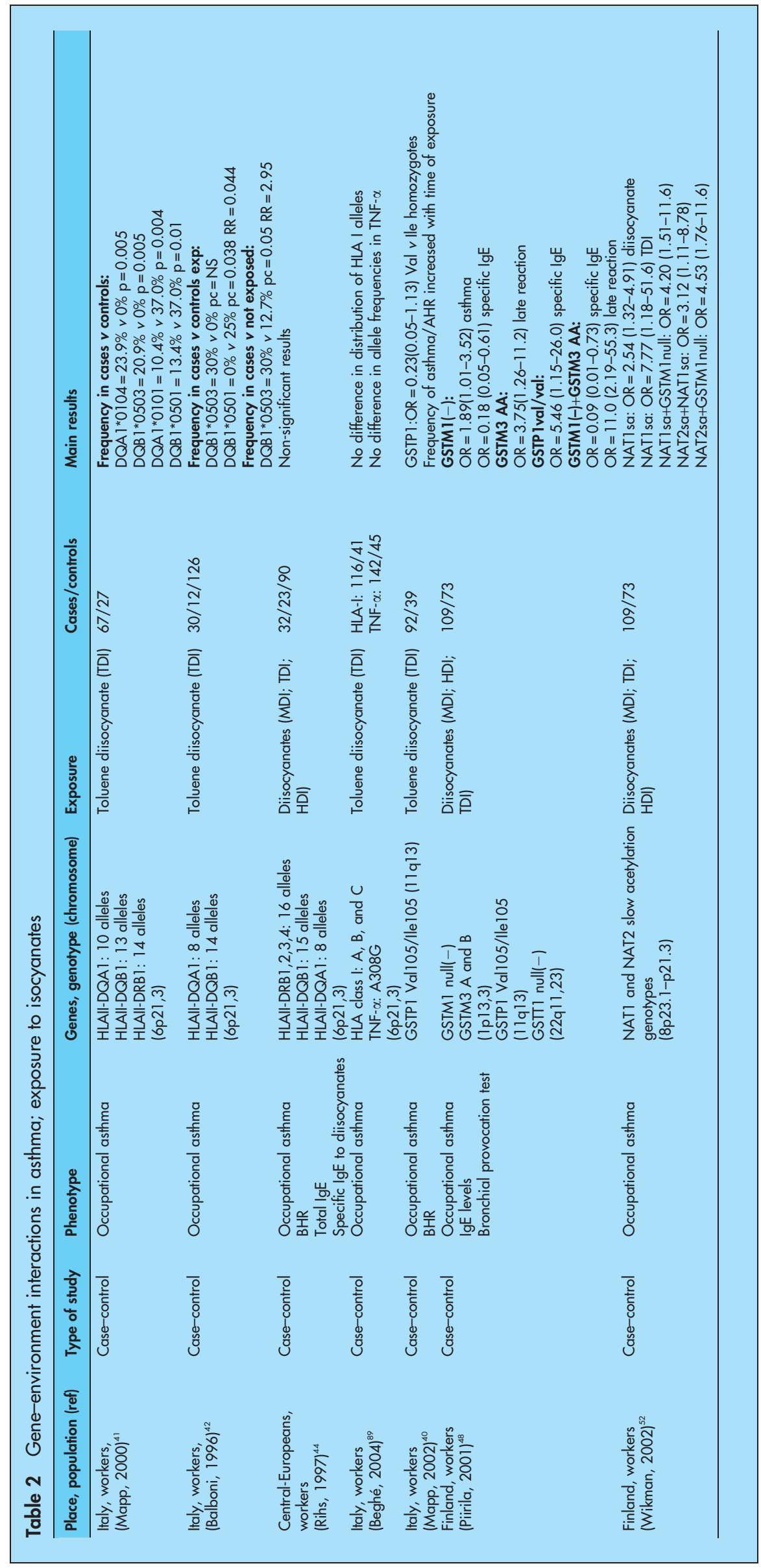




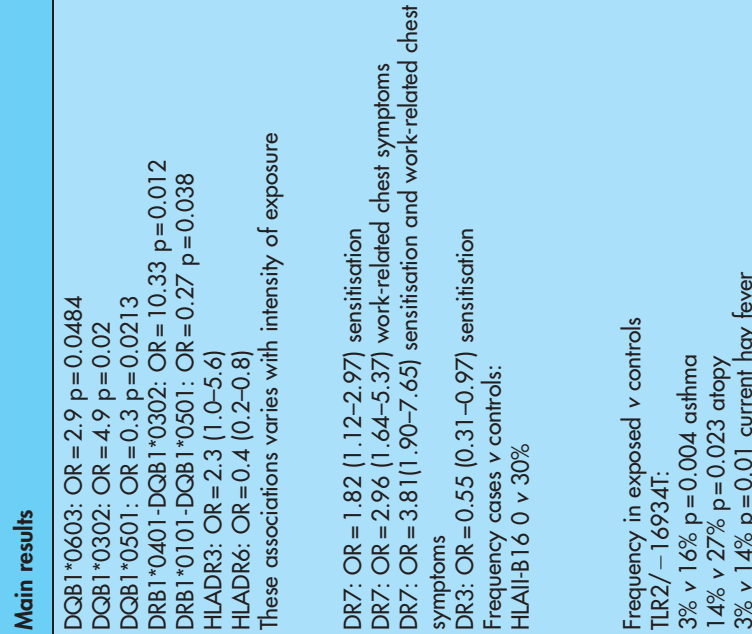

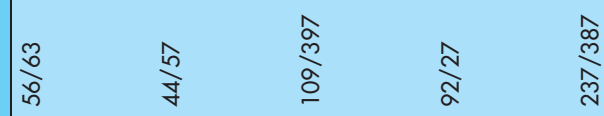
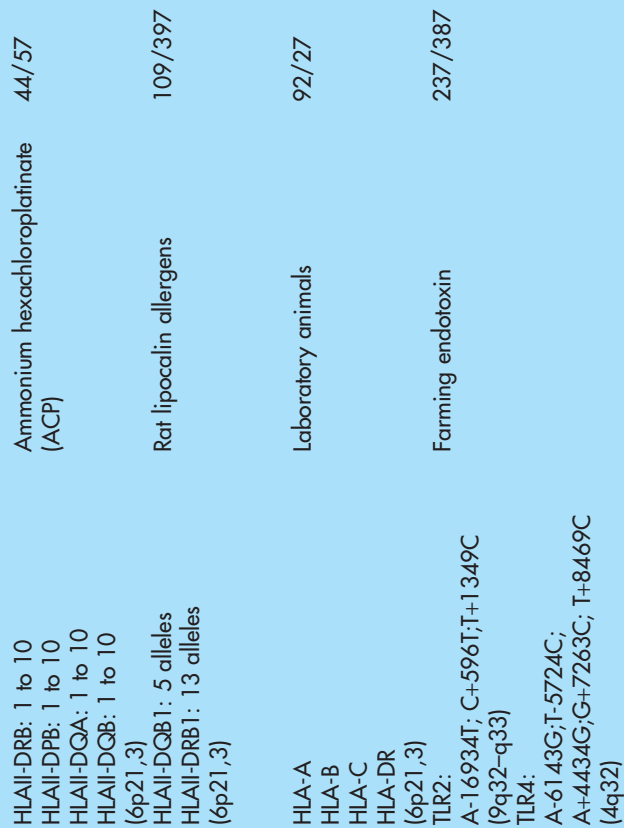

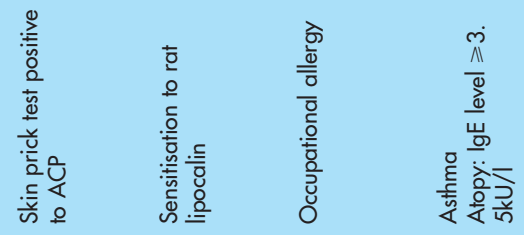

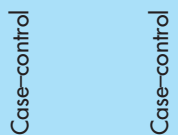

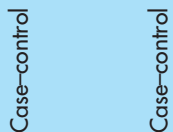

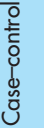

可

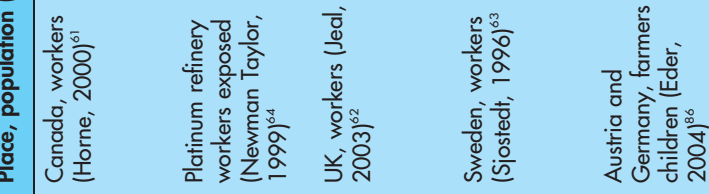




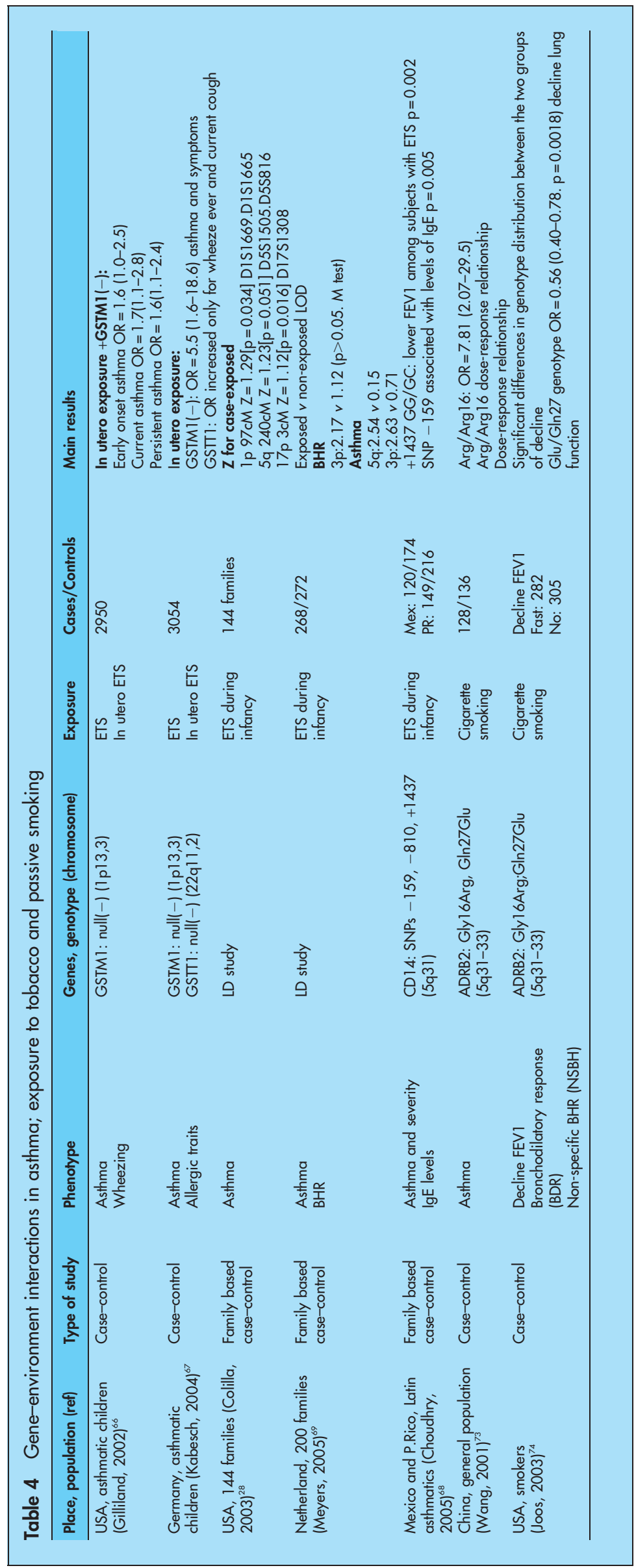




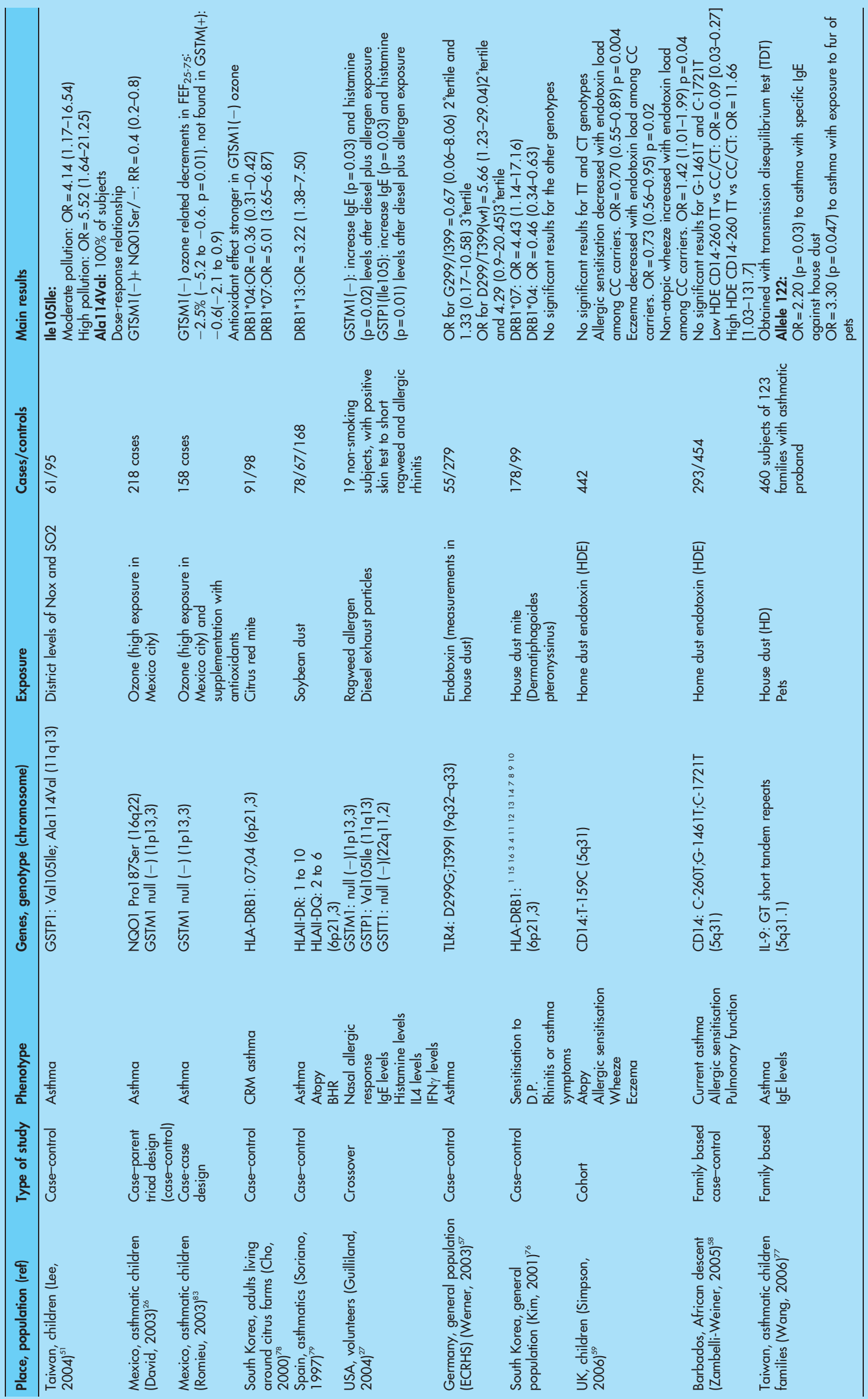


whereas the ${ }^{*} 03$ genotype was associated with a protective effect to sensitisation ( $\mathrm{OR}=0.5 ; 95 \%$ CI 0.3 to 1.0 ). HLAIIDRB3 could convey a risk ( $\mathrm{OR}=2.3 ; 95 \% \mathrm{CI} 1.0$ to 5.6$)$ and HLAII-DRB6 a protective role $(\mathrm{OR}=0.4 ; 95 \%$ CI 0.2 to 0.8$)$ for sensitisation to platinum salt complex, a well known cause of asthma. ${ }^{64}$

ENVIRONMENTAL EXPOSURES: SMOKING AND ETS Smoking and environmental tobacco smoke (ETS) have been extensively evaluated as risk factors of asthma. ETS is a major indoor air pollutant at home and at work that causes asthma in children and adults. ${ }^{65}$ Differences in the detoxification of tobacco smoke substances could modulate susceptibility to tobacco induced asthma.

Gilliland $e t a l^{66}$ assessed ETS and maternal smoking during pregnancy and genetic susceptibility in a sample based on a cohort study of 2950 children. They found that children with GSTM1 null genotype exposed to tobacco in utero, had a high risk of asthma and asthma symptoms (early onset, asthma with current symptoms, persistent asthma, lifetime history of wheezing, wheezing without exercise, wheezing requiring medication, and emergency room visits in the past years). Similar results were found for ETS exposure in the study by Kabesch et $a{ }^{67}$ in relation to asthma and asthma symptoms (wheeze ever, current wheezing, shortness of breath). A study carried out in young asthmatics found that CD14 genotypes GG or GC for the polymorphism at +1437 position were associated with lower pre-FEVl $(\mathrm{p}=0.002)$, and a interaction between SNP polymorphism at -159 and levels of $\operatorname{IgE}(\mathrm{p}=0.005) .^{68}$

ETS exposure during infancy and asthma was assessed in another study that examined interactions in a genome-wide multipoint linkage analysis. ${ }^{28}$ This study found a positive interaction in chromosome regions $1 \mathrm{p}, 5 \mathrm{q}, 17 \mathrm{p}$ and negative interaction in lq, 6p, 9q regions. A similar study was carried out by Meyers et $a l^{69}$ and observed association with regions $3 p$ and $5 \mathrm{q}$ for asthma, and $3 \mathrm{p}$ for BHR. An innovative aspect of both studies is the demonstration that the effect of some genes may only be evaluated in relation to specific exposures.

Inflammatory mechanisms have been examined in relation to tobacco induced asthma. $\beta 2$-Adrenergic receptor $(\beta 2 \mathrm{AR})$ is involved in muscular contraction and plays an anti-inflammatory role in airway smooth muscle. Cigarette smoking has been assessed in relation with polymorphisms Glyl6Arg and Gln27Glu of $\beta 2 A R$. Two initial studies found an association of these two polymorphisms with asthma. ${ }^{70}$ A recent metaanalysis $^{72}$ has confirmed these associations. Wang et $\mathrm{l}^{73}$ did not find an association of polymorphism in residue 27 in ever smokers, but observed an interaction in the case of polymorphism in position $16(\mathrm{OR}=7.8 ; 95 \%$ CI 2.1 to 29$)$ and also observed a higher risk for homozygotes for Argl6 variant. Different results were obtained in the study by Joos et $a l^{74}$ that found an interaction with smoking in position 27 and not in position 16. However, the phenotype evaluated in this study was the rate of decline of lung function rather than asthma.

\section{ENVIRONMENTAL EXPOSURES: OUTDOOR AND INDOOR AIR POLLUTION}

Studies examining outdoor air pollution evaluated diesel exhaust particles, $\mathrm{NO}_{\mathbf{x}}, \mathrm{SO}_{2}$, and ozone. Diesel exhaust particles in combination with ragweed allergens have been evaluated in an experimental study showing that individuals with the GSTMI null genotype and GSTPl Ile/Ile105 polymorphism showed an enhanced nasal allergic response in the presence of diesel exhaust particles. ${ }^{27}$ Lee et $a l^{51}$ observed that GSTP1 Ile105 homozygote carriers have a higher risk of asthma produced by outdoor air pollution defined by levels of $\mathrm{NO}_{\mathrm{x}}$ and $\mathrm{SO}_{2}(\mathrm{OR}=5.5 ; 95 \%$ CI 1.6 to 21.3). Several genes were examined in a study by Winterton et $a l^{75}$ including ADRB2, IL4R-a, CC16, TNF, LT $\alpha$ and NQO1. Only TNF seemed to interact with response to $\mathrm{SO}_{2}$ among asthmatics subjects (OR $=16.25 ; 95 \%$ CI 1.5 to infinite). Among GSTMI null carriers, David et al ${ }^{26}$ found a protective role of the NQ01 position 187 polymorphism in ozone induced asthma ( $\mathrm{RR}=0.4 ; 95 \% \mathrm{CI} 0.2$ to 0.8$)$ among subjects that carried at least one Ser allele. The study was carried out in Mexico city with high levels of ozone. In this same study, dietary supplementation with antioxidants was more beneficial for GSTM1 null genotype carriers.

Five studies evaluated indoor air pollutants other than ETS. One study found a non-significant interaction between genotype G299/I399 of TLR4 and home levels of endotoxin in asthma and BHR (OR $=0.67 ; 95 \%$ CI 0.06 to 8.06). ${ }^{57} \mathrm{~A}$ second study examining home endotoxin did not find significant interactions of genotypes G-1461T and C-1721T of CDI4. In the same study it was found that genotype -260 TT had a protective role at low levels of exposure $(\mathrm{OR}=0.09$; 95\% CI 0.03 to 0.3 ) but could be a risk factor at high levels $(\mathrm{OR}=11.7 ; 95 \%$ CI 1.0 to 131.7$) ..^{58} \mathrm{~A}$ possible interaction between CD14 and endotoxin load were also observed in the study by Simpson et al, ${ }^{59}$ that found low allergic sensitisation $(\mathrm{OR}=0.70 ; 95 \%$ CI 0.55 to 0.89$)$ and eczema $(\mathrm{OR}=0.73 ; 95 \%$ CI 0.56 to 0.95 ) among CC carriers of polymorphism T-159C. However, they observe an increased risk of non-atopic wheeze with increasing endotoxin exposure in CC children ( $\mathrm{OR}=1.42 ; 95 \%$ CI 1.01 to 1.99$)$.

The fourth study examined HLA-DRBl and exposure to house dust mite (D pteronyssinus) in relation to asthma. It was found that genotype *07 could be involved in susceptibility to $D$ pteronyssinus ( $\mathrm{OR}=4.4 ; 95 \% \mathrm{CI} 1.1$ to 17.2 ) and *04 could have a protective effect $(\mathrm{OR}=0.5 ; 95 \%$ CI 0.3 to 0.6$) .{ }^{76}$ Home dust was also studied in interaction with GT short tandem repeats of interleukin $9 .^{77}$ Allele 122 was related to asthma with specific IgE against house dust $(\mathrm{OR}=2.22 ; \mathrm{p}=0.03)$ and asthma with exposure to fur of pets $(\mathrm{OR}=3.30 ; \mathrm{p}=0.047)$.

\section{OTHER ENVIRONMENTAL EXPOSURES}

Other environmental exposures that have been evaluated were citrus red mite and soybean dust, both in relation to HLA class II genes. ${ }^{78}{ }^{79}$ HLAII-DRB $1^{*} 04$ conferred protection to asthma produced by citrus red mite (OR $=0.4 ; 95 \%$ CI 0.3 to 0.42 ), whereas DRB 07 genotype was associated with an increased risk $(\mathrm{OR}=5.01 ; 95 \%$ CI 3.65 to 6.87$) .{ }^{78}$ Soriano et $a l^{79}$ found that the presence of DRB 13 genotype conferred a high risk of asthma in epidemics due to soybean dust among those with low levels of IgE (OR $=3.2 ; 95 \%$ CI $1.4-7.5$ ).

\section{DISCUSSION}

Research on the causes of complex diseases has shown the necessity of evaluating both genetic and environmental components to understand the pathogenesis of these diseases. ${ }^{20}$ Asthma is a complex disease with a heterogeneous genetic and environmental component. The increase in the prevalence of asthma during the past decades can only be explained by changes in the environment. This however does not preclude that a genetic component plays an important role in the occurrence and severity of asthma, and several lines of research have shown that a genetic component in the 
aetiology of asthma is high..$^{6-9}$ After many years of research, only few environmental factors have been shown without doubt to cause asthma, many of them occurring in the occupational environment. More than 30 studies have evaluated gene-environment interactions in asthma. Despite this relatively high number of studies, only modest advances have been achieved in our understanding of the relevance of genetic background in the causation of asthma in relation to environmental exposures. Research has been hampered by studies based on small numbers, studies examining distinct exposures and genes, and not always comparable phenotypes.

Only nine of 30 studies identified enrolled more than 500 subjects. Due to heterogeneity in design it is not possible to do meta-analyses that would circumvent the problem of reduced statistical power in individual studies. Most studies had very low statistical power to detect interactions or to reasonably exclude false positive results, with only nine studies examining more than 500 subjects. Availability of low cost, high throughput methods has led to a flood of data on genetic factors and disease. Failure to replicate results from studies reporting genetic associations has led to scepticism on the validity of such studies. ${ }^{80}{ }^{81}$ A high proportion of false positive results and failure to replicate has been attributed to several factors including small sample size. Other factors that may contribute are problems in design such as poorly matched control groups, unwarranted candidate genes, linkage disequilibrium, genetic heterogeneity between populations, differences in definitions of phenotypes and in the evaluation of environmental factors, chance due to multiple testing, and publication bias of positive results. ${ }^{80} 81$ Small studies are probably more prone to several of these biases than larger ones.

The large number of genes potentially involved in asthma complicates substantially the evaluation of gene-environment interactions. More than 35 genes (or if using less strict criteria, around 100 genes) have been associated with asthma pathology and susceptibility. ${ }^{82}$ These genes have been identified by gene expression, candidate gene, and mapping broad regions identified by genome-wide linkage studies. Several of these genes have been examined in studies on gene-environment interaction. The model approach in these studies is the evaluation of one gene with one exposure. Due to the complexity of the pathobiological mechanisms leading to asthma, the expected effect for the interaction of one gene with one exposure should be expected to be low. Large effects could be expected if the main effects of single genes or exposures were very strong. However, even the most replicated genetic findings, such as those for ADAM $33,{ }^{82}$ indicate that the main gene effect is of the order of a $50 \%$ increased risk. Selection of genes involved in the same pathway of the disease (e.g. genes involved in the modulation of oxidative stress), and the subsequent analysis on the whole pathway could lead to the identification of larger relative or absolute effects and could help identify the risk contribution of environmental exposures in genetically different populations. These studies are more complex concerning the evaluation of exposures, genes, and analysis, and will require larger samples.

Most studies examining gene-environment interactions apply a case-control design sampling from the general population or are family based. Case-control designs are optimal for the evaluation of genetic traits ${ }^{20}$ but are affected by potential biases in exposure assessment. This may be particularly important in the evaluation of specific exposures such as endotoxin that may occur in early life and differentially affect asthma risk compared to exposure at later ages. Cohort studies are, in principle, less prone to exposure misclassification, but only few such studies are available.

Findings of the around 30 studies evaluating geneenvironment interactions in asthma clearly indicate the importance of these interactions in causing asthma and related phenotypes. These studies, however, provide few concrete findings on such interactions. Among the most consistent results are those for HLAII-DQB1 and exposure to isocyanates and the studies on smoking and ETS in relation to genes of the GST family. Among the most suggestive findings are those examining the modulation of the effect of GSTMI null phenotype in relation to ozone exposure through supplementation with antioxidants vitamins. ${ }^{83}$ Further promising findings that have not been completely replicated but that are largely based on the concept of the hygiene hypothesis and that appear biologically plausible are those referring to endotoxin exposure (a potent inflammatory agent present in dust) in connection with the CD14-159 TT polymorphism. ${ }^{84} \mathrm{CD} 14$ is part of the receptor complex for endotoxin and has an important role in innate immune response. Other factors including Toll-like receptor polymorphisms such as TLR4 could also modify the effect of endotoxin in asthma..$^{57} 588886$

Other well described limitations of epidemiological studies of asthma also hinder the interpretation of these studies, including the difficulties of standardised phenotype definitions of asthma, atopy, or BHR, and difficulties in exposure assessment that leads to misclassification of exposure. New studies should better characterise, standardise, and give an explicit description of phenotypes and exposures. In addition, new methods of statistical analysis and strategies for analysis should be applied, including those that help reduce the number of reported false positives within each study..$^{20}$ The large number of potential interactions between genes and environmental exposures and their complexity, clearly shows the need to conduct large studies that will allow the deduction of solid results. ${ }^{88}$ Research in this field should allow a better understanding of the complexity of asthma aetiology, the identification of populations at risk, and, in the future, the design of new preventive and therapeutic strategies. ${ }^{11}$

\section{ACKNOWLEDGEMENTS}

This research was partly support by EU Framework program for research contract No. FOOD_CT_2004_506378, the Ga2len project, Global Allergy and Asthma European Network, and by Grant 40110 of the Marató TV3, Catalonia, Spain.

\footnotetext{
Authors' affiliations

F Castro-Giner, Centre for Research in Environmental Epidemiology, Municipal Institute of Medical Research (IMIM), Barcelona, Spain F Kauffmann, Inserm, U780 Epidemiology and Biostatistics, Villejuif, France, and Université Paris Sud, Faculté de Médecine, IFR69, Villejuif, France

R de Cid, Genes and Disease Program, Centre for Genomic Regulation and Universitat Pompeu Fabra, Barcelona, Spain M Kogevinas, Centre for Research in Environmental Epidemiology, Municipal Institute of Medical Research (IMIM), Barcelona, Spain and Medical School, University of Crete, Heraklion, Greece

Competing interests: none
} 


\section{REFERENCES}

1 Cookson W. The alliance of genes and environment in asthma and allergy. Nature 1999;402:B5-11.

- Good review about increasing asthma rates, environmental factors, and genetics of asthma.

2 Sennhauser FH, Braun-Fahrlander C, Wildhaber JH. The burden of asthma in children: a European perspective. Paediatr Respir Rev 2005;6:2-7

3 Sengler C, Lau S, Wahn U, et al. Interactions between genes and environmental factors in asthma and atopy: new developments. Respir Res 2002;3:7.

4 Weiss ST, Raby BA. Asthma genetics 2003. Human Molecular Genetics 2004; 13:R83-9.

5 The International Study of Asthma and Allergies in Childhood (ISAAC) Steering Committee. Worldwide variation in prevalence of symptoms of asthma, allergic rhinoconjunctivitis, and atopic eczema: ISAAC. Lancet 1998; $351: 1225-32$

6 Duffy DL, Martin NG, Battistutta D, et al. Genetics of asthma and hay fever in Australian twins. Am Rev Respir Dis 1990;142:1351-8.

7 Nieminen MM, Kaprio J, Koskenvuo M. A population-based study of bronchial asthma in adult twin pairs. Chest 1991;100:70-5.

8 Skadhauge LR, Christensen K, Kyvik KO, et al. Genetic and environmental influence on asthma: a population-based study of 11,688 Danish twin pairs. Eur Respir J 1999;13:8-14.

9 Los H, Koppelman GH, Postma DS. The importance of genetic influences in asthma. Eur Respir J 1999;14:1210-27.

10 Malerba G. Pignatti PF. A review of asthma genetics: gene expression studies and recent candidates. J Appl Genet 2005;46:93-104.

- Complete review about genes found to be involved in asthma.

11 Bernstein JA, Alexis N, Barnes C, et al. Health effects of air pollution. J Allergy Clin Immunol 2004;114:1116-23.

12 Peden DB. The epidemiology and genetics of asthma risk associated with air pollution. J Allergy Clin Immunol 2005;1 15:213-19.

13 Delfino RJ. Epidemiologic evidence for asthma and exposure to air toxics: inkages between occupational, indoor, and community air pollution research. Environ Health Perspect 2002;1 10(suppl 4):573-89.

14 Chan-Yeung $M$, Dimich-Ward $H$. Respiratory health effects of exposure to environmental tobacco smoke. Respirology 2003;8:131-9.

15 Blanc PD, Toren K. How much adult asthma can be attributed to occupational factors? Am J Med 1999:107:580-7.

16 Kogevinas M, Anto JM, Sunyer J, et al. Occupational asthma in Europe and other industrialised areas: a population-based study. European Community Respiratory Health Survey Study Group. Lancet 1999;353:1750-4.

17 Braun-Fahrlander C Riedler J, Herz U, et al. Environmental exposure to endotoxin and its relation to asthma in school-age children. N Engl J Med 2002;347:869-77

18 Schram-Bijkerk D, Doekes G, Douwes J, et al. Bacterial and fungal agents in house dust and wheeze in children: the PARSIFAL study. Clin Exp Allergy 2005; 35: 1272-8.

- Good example of the importance of timing of exposure in the aetiology of asthma.

19 Umetsu DT, Mclntire JJ, Akbari O, et al. Asthma: an epidemic of dysregulated immunity. Nat Immunol 2002;3:715-20.

20 Hunter DJ. Gene-environment interactions in human diseases. Nat Rev Genet 2005;6:287-98

- Good article on studies of gene environment interactions in complex diseases, types of study designs and models of interaction.

21 Clayton D, McKeigue PM. Epidemiological methods for studying genes and environmental factors in complex diseases. Lancet 2001;358:1356-60.

- Another good paper about theory of interactions and usefulness of their study.

22 Cooper RS. Gene-environment interactions and the etiology of common complex disease. Ann Intern Med 2003;139:437-40.

23 Akahoshi M, Obara K, Hirota T, et al. Functional promoter polymorphism in the TBX21 gene associated with aspirin-induced asthma. Hum Genet 2005; 117:16-26.

24 Dekker JW, Nizankowska E, Schmitz-Schumann M, et al. Aspirin-induced asthma and HLA-DRB1 and HLA-DPB1 genotypes. Clin Exp Allergy 1997; $27: 574-7$

25 Jinnai N, Sakagami T, Sekigawa T, et al. Polymorphisms in the prostaglandin E2 receptor subtype 2 gene confer susceptibility to aspirin-intolerant asthma: a candidate gene approach. Hum Mol Genet 2004;13:3203-17.

26 David GL, Romieu I, Sienra-Monge JJ, et al. Nicotinamide adenine dinucleotide (phosphate) reduced: quinone oxidoreductase and glutathione $\mathrm{S}$ transferase M1 polymorphisms and childhood asthma. Am J Respir Crit Care Med 2003;168:1199-204.

- Interesting example of an experimental study design for evaluation of gene environment interaction.

27 Gilliland FD, Li YF, Saxon A, et al. Effect of glutathione-S-transferase M1 and P1 genotypes on xenobiotic enhancement of allergic responses: randomised, placebo-controlled crossover study. Lancet 2004;363:119-25.

28 Colilla S, Nicolae D, Pluzhnikov A, et al. Evidence for gene-environment interactions in a linkage study of asthma and smoking exposure. J Allergy Clin Immunol 2003;111:840-6.

- Good example about study of gene environment interactions using a linkage approach.

29 Cordell HJ, Clayton DG. Genetic association studies. Lancet 2005:366:1121-31.

30 Tabor HK, Risch NJ, Myers RM. Candidate-gene approaches for studying complex genetic traits: practical considerations. Nat Rev Genet 2002;3:391-6.
Proposed article to extend knowledge about candidate gene approach.

31 Gao PS, Huang SK. Genetic aspects of asthma. Panminerva Med 2004;46:121-34

32 Chan-Yeung M, Malo JL. Aetiological agents in occupational asthma. Eur Respir J 1994;7:346-71.

33 Mapp CE. Agents, old and new, causing occupational asthma. Occup Environ Med 2001;58:354-60.

- Complete review and educational article about occupational risks factors of asthma.

34 Mapp CE, Balboni A, Baricordi R, et al. Human leukocyte antigen associations in occupational asthma induced by isocyanates. Am J Respir Crit Care Med 1997; 156:S139-43.

35 Bernstein DI, Jolly A. Current diagnostic methods for diisocyanate induced occupational asthma. Am J Ind Med 1999;36:459-68.

36 Elms J, Beckett PN, Griffin P, et al. Mechanisms of isocyanate sensitisation. An in vitro approach. Toxicol In Vitro 2001;15:631-4.

37 Redlich CA, Stowe MH, Wisnewski AV, et al. Subclinical immunologic and physiologic responses in hexamethylene diisocyanate-exposed auto body shop workers. Am J Ind Med 2001;39:587-97.

38 Bentley AM, Maestrelli P, Saetta M, et al. Activated T-lymphocytes and eosinophils in the bronchial mucosa in isocyanate-induced asthma. J Allergy Clin Immunol 1992;89:821-9.

39 Saetta M, Di Stefano A, Maestrelli P, et al. Airway mucosal inflammation in occupational asthma induced by toluene diisocyanate. Am Rev Respir Dis 1992;145:160-8.

40 Mapp CE, Fryer AA, De Marzo N, et al. Glutathione S-transferase GSTP1 is a susceptibility gene for occupational asthma induced by isocyanates. J Allergy Clin Immunol 2002;109:867-72.

41 Mapp CE, Beghe B, Balboni A, et al. Association between HLA genes and susceptibility to toluene diisocyanate-induced asthma. Clin Exp Allergy 2000;30:651-6.

42 Balboni A, Baricordi OR, Fabbri LM, et al. Association between tolvene diisocyanate-induced asthma and DQB1 markers: a possible role for aspartic acid at position 57. Eur Respir J 1996;9:207-10.

43 Bignon JS, Aron Y, Ju LY, et al. Hla Class-Il alleles in isocyanate-induced asthma. Am J Respir Crit Care Med 1994;149:71-5.

44 Rihs HP, Krolls TB, Huber $\mathrm{H}$, et al. No evidence for the influence of HLA class II in alleles in isocyanate-induced asthma. Am J Ind Med 1997;32:522-7.

45 Bernstein JA, Munson J, Lummus ZL, et al. T-cell receptor V beta gene segment expression in diisocyanate-induced occupational asthma. J Allergy Clin Immunol 1997;99:245-50.

46 Berode $M$, Jost $M$, Ruegger $M$, et al. Host factors in occupational diisocyanate asthma: a Swiss longitudinal study. Int Arch Occup Environ Health 2005;78:158-63

47 Caramori G Papi A. Oxidants and asthma. Thorax 2004:59:170-3.

48 Piirila P, Wikman H, Luukkonen R, et al. Glutathione S-transferase genotypes and allergic responses to diisocyanate exposure. Pharmacogenetics 2001;11:437-45

49 Fryer AA, Bianco A, Hepple $M$, et al. Polymorphism at the glutathione Stransferase GSTP1 locus - a new marker for bronchial hyperresponsiveness and asthma. Am J Respir Crit Care Med 2000;161:1437-42.

50 Tamer L, Calikoglu M, Ates NA, et al. Glutathione-S-transferase gene polymorphisms (GSTT1, GSTM1, GSTP1) as increased risk factors for asthma. Respirology 2004;9:493-8.

51 Lee YL, Lin YC, Lee YC, et al. Glutathione S-transferase P1 gene polymorphism and air pollution as interactive risk factors for childhood asthma. Clin Exp Allergy 2004;34:1707-13.

52 Wikman $\mathrm{H}$, Piirila $\mathrm{P}$, Rosenberg $\mathrm{C}$, et al. N-Acetyltransferase genotypes as modifiers of diisocyanate exposure-associated asthma risk. Pharmacogenetics 2002; 12:227-33

53 Arnaiz NO, Kaufman JD, Daroowalla FM, et al. Genetic factors and asthma in aluminum smelter workers. Arch Environ Health 2003;58:197-200.

54 Mackay IR, Oliphant RC, Laby B, et al. An immunologic and genetic study of asthma in workers in an aluminum smelter. J Occup Med 1990;32:1022-6.

55 Young RP, Barker RD, Pile KD, et al. The association of HLA-DR3 with specific lgE to inhaled acid anhydrides. Am J Respir Crit Care Med 1995; 151:219-21.

56 Jones MG, Nielsen J, Welch J, et al. Association of HLA-DQ5 and HLA-DR 1 with sensitization to organic acid anhydrides. Clin Exp Allergy 2004;34:812-16.

57 Werner M, Topp R, Wimmer K, et al. TLR4 gene variants modify endotoxin effects on asthma. J Allergy Clin Immunol 2003;112:323-30.

58 Zambelli-Weiner A, Ehrlich E, Stockton ML, et al. Evaluation of the CD14/260 polymorphism and house dust endotoxin exposure in the Barbados Asthma Genetics Study. J Allergy Clin Immunol 2005;115:1203-9.

59 Simpson A, John SL, Jury F, et al. Endotoxin exposure, CD14 and allergic disease: an interaction between genes and the environment. Am J Respir Crit Care Med, 2006;13 Apr [Epub ahead of print].

60 Sigsgaard T, Brandslund I, Omland O, et al. S and Z alphal-antitrypsin alleles are risk factors for bronchial hyperresponsiveness in young farmers: an example of gene/environment interaction. Eur Respir J 2000;16:50-5.

61 Horne C, Quintana PJ, Keown PA, et al. Distribution of DRB1 and DQB1 HLA class II alleles in occupational asthma due to western red cedar. Eur Respir J 2000;15:911-14.

62 Jeal H, Draper A, Jones M, et al. HLA associations with occupational sensitization to rat lipocalin allergens: a model for other animal allergies? J Allergy Clin Immunol 2003;111:795-9.

63 Sjostedt L, Willers S, Orbaek P. Human leukocyte antigens in occupational allergy: a possible protective effect of HLA-B16 in laboratory animal allergy. Am J Ind Med 1996:30:415-20. 
64 Newman Taylor AJ, Cullinan P, Lympany PA, et al. Interaction of HLA phenotype and exposure intensity in sensitization to complex platinum salts. Am J Respir Crit Care Med 1999;160:435-8.

65 Rushton L. Health impact of environmental tobacco smoke in the home. Rev Environ Health 2004;19:291-309.

66 Gilliland FD, Li YF, Dubeau L, et al. Effects of glutathione S-transferase MI, maternal smoking during pregnancy, and environmental tobacco smoke on asthma and wheezing in children. Am J Respir Crit Care Med 2002; 166:457-63.

67 Kabesch M, Hoefler C, Carr D, et al. Glutathione S transferase deficiency and passive smoking increase childhood asthma. Thorax 2004;59:569-73.

68 Choudhry S, Avila PC, Nazario S, et al. CD14 Tobacco gene-environment interaction modifies asthma severity and immunoglobulin $E$ levels in Latinos with asthma. Am J Respir Crit Care Med 2005;172:173-82.

69 Meyers DA, Postma DS, Stine OC, et al. Genome screen for asthma and bronchial hyperresponsiveness: interactions with passive smoke exposure. J Allergy Clin Immunol 2005; 115:1 169-75.

70 Weir TD, Mallek N, Sandford AJ, et al. beta2-Adrenergic receptor haplotypes in mild, moderate and fatal/near fatal asthma. Am J Respir Crit Care Med 1998;158:787-91.

71 Hall IP, Wheatley A, Wilding P, et al. Association of Glu 27 beta 2adrenoceptor polymorphism with lower airway reactivity in asthmatic subjects. Lancet 1995;345:1213-14.

72 Thakkinstian A, McEvoy M, Minelli C, et al. Systematic review and metaanalysis of the association between \{beta\}2-adrenoceptor polymorphisms and asthma: a HuGE review. Am J Epidemiol 2005;162:201-11.

73 Wang Z, Chen C, Niu T, et al. Association of asthma with beta(2)-adrenergic receptor gene polymorphism and cigarette smoking. Am J Respir Crit Care Med 2001; 163:1404-9.

74 Joos L, Weir TD, Connett JE, et al. Polymorphisms in the beta2 adrenergic receptor and bronchodilator response, bronchial hyperresponsiveness, and rate of decline in lung function in smokers. Thorax 2003:58:703-7.

75 Winterton DL, Kaufman J, Keener CV, et al. Genetic polymorphisms as biomarkers of sensitivity to inhaled sulfur dioxide in subjects with asthma. Ann Allergy Asthma Immunol 2001;86:232-8.

$76 \mathrm{Kim}$ YK, Oh HB, Oh SY, et al. HLA-DRB $1{ }^{*} 07$ may have a susceptibility and $\mathrm{DRB} 1{ }^{*} 04$ a protective effect upon the development of a sensitization to house dust mite Dermatophagoides pteronyssinus. Clin Exp Allergy 2001;31:110-15.

77 Wang TN, Chen WY, Huang YF, et al. The synergistic effects of the IL-9 gene and environmental exposures on asthmatic Taiwanese families as determined by the transmission/disequilibrium test. Int J Immunogenet 2006;33:105-10.

$78 \mathrm{Cho} \mathrm{SH}, \mathrm{Kim}$ YK, Oh HB, et al. Association of HLA-DRB1(*)07 and DRB1(*)04 to citrus red mite (Panonychus citri) and house dust mite sensitive asthma. Clin Exp Allergy 2000;30:1568-75.

79 Soriano JB, Ercilla G, Sunyer J, et al. HLA class II genes in soybean epidemic asthma patients. Am J Respir Crit Care Med 1997;156:1394-8.

80 loannidis JP, Ntzani EE, Trikalinos TA, et al. Replication validity of genetic association studies. Nat Genet 2001;29:306-9.

81 Colhoun HM, McKeigue PM, Davey SG. Problems of reporting genetic associations with complex outcomes. Lancet 2003;361:865-872.

82 Ober C. Perspectives on the past decade of asthma genetics. J Allergy Clin Immunol 2005; 1 16:274-8.

83 Romieu I, Sienra-Monge JJ, Ramirez-Aguilar M, et al. Genetic polymorphism of GSTM1 and antioxidant supplementation influence lung function in relation to ozone exposure in asthmatic children in Mexico City. Thorax 2004;59:8-10.

84 Gern JE, Reardon CL, Hoffjan S, et al. Effects of dog ownership and genotype on immune development and atopy in infancy. J Allergy Clin Immunol 2004:113:307-14.

85 Park JH, Spiegelman DL, Gold DR, et al. Predictors of airborne endotoxin in the home. Environ Health Perspect 2001; 109:859-64.

86 Eder W, Klimecki W, Yu L, et al. Toll-like receptor 2 as a major gene for asthma in children of European farmers. J Allergy Clin Immunol 2004; 113:482-8.

87 Efron B, Tibshirani R. Empirical bayes methods and false discovery rates for microarrays. Genet Epidemiol 2002;23:70-86.

88 Mapp CE. The role of genetic factors in occupational asthma. Eur Respir J 2003:22:173-8.

89 Beghe B, Padoan M, Moss CT, et al. Lack of association of HLA class I genes and TNF alpha-308 polymorphism in toluene diisocyanate-induced asthma. Allergy 2004;59:61-4.

\section{QUESTIONS (SEE ANSWERS ON P 761)}

Which response is true in each case?

(1) The candidate gene approach

(a) Is always preceded by a whole genome scan

(b) Is applied to examine a list of a priori selected genes (c) Has the advantage that it is entirely based on a statistical (Bayesian) approach

(d) Is based on a selection of tagSNPs from the HapMap project following a random selection of chromosomes

(e) Is not applicable when examining gene-environment interactions because the meaning of interaction by definition denies the use of candidate genes

(2) About gene-environment or gene-gene interactions:

(a) Genes have been shown to be related to asthma only through the interaction with specific environmental exposures

(b) Gene-gene interactions always imply a multiplicative effect between the two genes

(c) Interactions of specific genes with specific environmental exposures are likely to have large effects on asthma risk

(d) One of the main problems of studies on geneenvironment interactions has been errors in genotyping

(e) One of the main problems of studies on geneenvironment interactions has been the lack of replication of original findings

(3) About study design to evaluate interactions:

(a) Case-case studies evaluate main effects of genes and environmental factors and also their interaction

(b) Most studies on gene-environment interaction in asthma had sufficient statistical power to detect these interactions

(c) Bias due to population stratification can be avoided through family based case-control design

(d) Genome-wide scans have been mainly used to confirm old hypotheses

(e) Cohort studies cannot evaluate gene-environment interactions

(4) About isocyanates:

(a) There is evidence that isocyanates interact with genes involved in immunological pathways

(b) Different studies show that the gene ADAM33, probably associated with airways remodelling, is involved in isocyanate induced asthma

(c) Persistent airway inflammation is not characteristic of isocyanate induced asthma

(d) Isocyanates cause $5-15 \%$ of all cases of occupational asthma

(e) Studies on HLA and workers exposed to isocyanates have shown that isocyanate induced asthma is principally a problem of atopic subjects

(5) Choose the false statement:

(a) Different studies have observed that ADRB2 interact with smoking

(b) GSTMI null polymorphism has been associated with asthma in children exposed to ETS (environmental tobacco smoke) in utero

(c) Endotoxin effects depend on the timing of exposure

(d) There is evidence of interaction between aluminium potroom emissions and GSTPl gene in asthmatic subjects

(e) There is evidence of interaction between polymorphisms in genes of the GST family and air pollution 